\title{
Processing of Virgin Coconut Oil in Sri Lanka Using Cold Extraction Method: An Economic Analysis
}

\author{
Pathiraja, P.M.E.K ${ }^{1}$, Fernando, M.T.N², Jayasundera, J.M.M.A ${ }^{3}$
}

\begin{abstract}
Virgin Coconut Oil (VCO) is a newly introduced product in Sri Lanka with a high export market potential. Only a few entrepreneurs however, are capitalizing on this opportunity due to several factors such as lack of rigorous economic analyses and unavailability of information on export market opportunities. Against this background, this study attempts to analyse the economic viability of this enterprise in Sri Lanka. Interestingly, it was found that the VCO provides the highest net return per 1000 coconuts utilized compared to the other traditional coconut kernel products. The pay-back period for the initial investment on machineries was little over a month under current prices of inputs and outputs. Sensitivity analysis suggests that the crucial factor that determines the economic viability of this enterprise is world market VCO price and the sensitivity of the net return of VCO production for the nut price is very low. The break-even price of one liter of VCO was found to be US \$4.8 whereas it receives US \$ 8 in the export market. This study concluded the need of encouraging VCO production in Sri Lanka, given the long-term brighter outlook of the global VCO industry.
\end{abstract}

Keywords: Economic viability, pay-back period, sensitivity, break-even price.

\footnotetext{
${ }^{1}$ Agricultural Economics Division, Coconut Research Institute, Lunuwila, Sri Lanka. Email: erandathiep@yahoo.com

${ }^{2}$ UNDP Asia-Pacific Regional Centre, 23, Independenence Avenue, Colombo 7, Sri Lanka. Email: neil.fernando@undp.org

${ }^{3}$ Coconut Processing Research Division, Coconut Research Institute, Lunuwila, Sri Lanka. Email: mithilajayasundera@yahoo.com
} 


\section{Introduction}

Virgin Coconut Oil (VCO) is a novel product derived from coconuts, with a growing export market potential. The global demand for $\mathrm{VCO}$ is growing for its nutritional and health benefits as well as its applicability as a beauty product (Floresca, 2004). Its inherent properties as a medium-chain triglyceride with high lauric acid content has resulted in VCO's growing demand as a health supplement (neutraceutical), a healthy premium food and oil for cooking and salad dressing (Romulo, 2003). The market for neutraceuticals is growing rapidly worldwide and the estimated US neutraceutical market alone is worth approximately US \$250 billions in addition Europe another US \$ 250 billions and Japan US \$ 4 billions (Carandang, 2005). VCO has a potential to capture the organic food market by catering to health conscious consumers especially in the European Union, North America and Japan the countries that have a large organic market. This organic sector is growing unprecedently at a rate of 20 to 25 percent per annum (Romulo, 2003).

The Philippines is the major supplier of VCO to the global market (Anon, 2007a). Malaysia and Thailand are fast moving in product development and are able to compete with the Philippines. The other countries entered into VCO production are Sri Lanka, India, Bangladesh, Indonesia, Papua New Guinea, Vietnam and the Pacific Islands (Sarian, 2007). The Philippines produces 2,931 metric tons of VCO annually, generating US \$ 1.5 million revenue from US alone in 2005 (Anon, 2007a). Apart from US, other countries demanding VCO are Australia and Canada. In Philippines, the export market for VCO expanded to 14 countries in 2005 from 8 in 2004 and USA accounted for 93.5\% of the total. Other markets included South Africa, South Korea, Singapore, Australia, Malaysia, Japan and the Netherlands (Anon, 2007a). New markets are in Ireland, UK, Germany, Sweden, Canada, Saudi Arabia, Hong Kong and New Zealand (Anon, 2007a).

There is a monthly demand of 20000 metric tons for VCO world wide with the price per kilogram at US \$ 8 in the export market (Anon, 2007b).

Sri Lanka is a late adopter of this technology entering into VCO production very recently using cold extraction method by which the oil is extracted at less than $60{ }^{0} \mathrm{C}$ temperature. The Coconut Research Institute of Sri Lanka (CRISL) disseminates this improved VCO-producing technology to entrepreneurs. The entrepreneurs willing to invest on this, request an economic analysis of the $\mathrm{VCO}$ production technology which unfortunately is unavailable.

Against this backdrop, this study was made to analyze the economic feasibility of VCO production; more specifically the ex-factory break-even price (BEP) of VCO. Further the BEP was compared with the f.o.b. price, with the purpose of providing an economic guideline for the investment decisions of prospectful VCO entrepreneurs in Sri Lanka. Moreover, the paper carried out a sensitivity analysis to determine the relative sensitivity of the profitability of $\mathrm{VCO}$ production to coconut price changes vis-à-vis VCO price changes.

\section{Materials and methods}

\section{Data}

Data were collected from Coconut Processing Research Division of Coconut Research Institute of Sri Lanka (CRISL), Central Bank publications, Coconut Development Authority Publications and through Internet.

\section{Analysis}

A break-even price (BEP) analysis was conducted using current prices of inputs and outputs, employing the following equation.

$$
\begin{gathered}
\text { BEP = Variable Cost/Unit }+ \text { Total Fixed costs } \\
\text { Projected unit sales } \\
\text { Production flow chart of VCO (Figure 1) } \\
\text { was used to guide the analysis and to identify } \\
\text { the technical co-efficients involved in the } \\
\text { different stages of production process (e.g. how }
\end{gathered}
$$


many nuts are required to produce a liter of VCO etc.) As was seen in Figure 1,1000 nuts produce 88.8L of VCO.

In calculating the BEP, income from byproducts such as defatted coconut residue and the income that would be generated from selling shells and husks were not considered.

\section{Results and Discussion}

Table 1 shows the cost analysis of VCO production. The factory-gate price of $500 \mathrm{ml}$ container (plastic wall bottle) is around Rs. 257 with a profit margin of $15 \%$.

The producers received US \$ 4 in 2007 and now receive US $\$ 8$ per one litre ${ }^{4}$ of VCO (FOB price) in Sri Lanka. This increase is due to the local nut price increase along with the global food price increase. As on February 2008, 1 US \$ was Rs. 107.00 (Central Bank of Sri Lanka, 2008). Based on this exchange rate, there is a considerable profit margin to the producers (around Rs.338 per litre) if this product is focused to the export market ${ }^{5}$. As Perera (2007) indicated, there are two mass scale VCO manufacturers in Sri Lanka and who aim the export market whilst promoting local market as well.

The Philippines receive US $\$ 8$ to 12 per litre in the export market. Papua New Guinea receives US \$3.3 per one kilogram of VCO in the export market and they export around 2 tons per annum.

Their sole buyer in Australia is Kokonut Pacific (Ovasuru, 2006).

\section{Figure 1: Production flow chart of VCO}

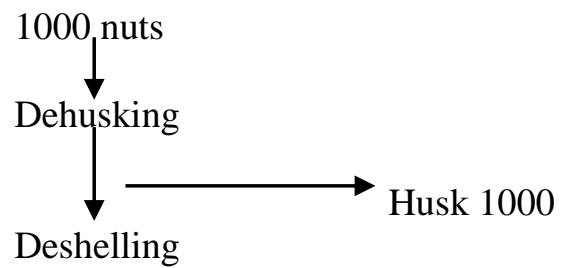

${ }^{4} 1$ kilogram of VCO equals 1.18 liters of VCO.

${ }^{5}$ Building cost, transportation costs and cost involved in obtaining safety standards (Ex. HACCP) are not included.

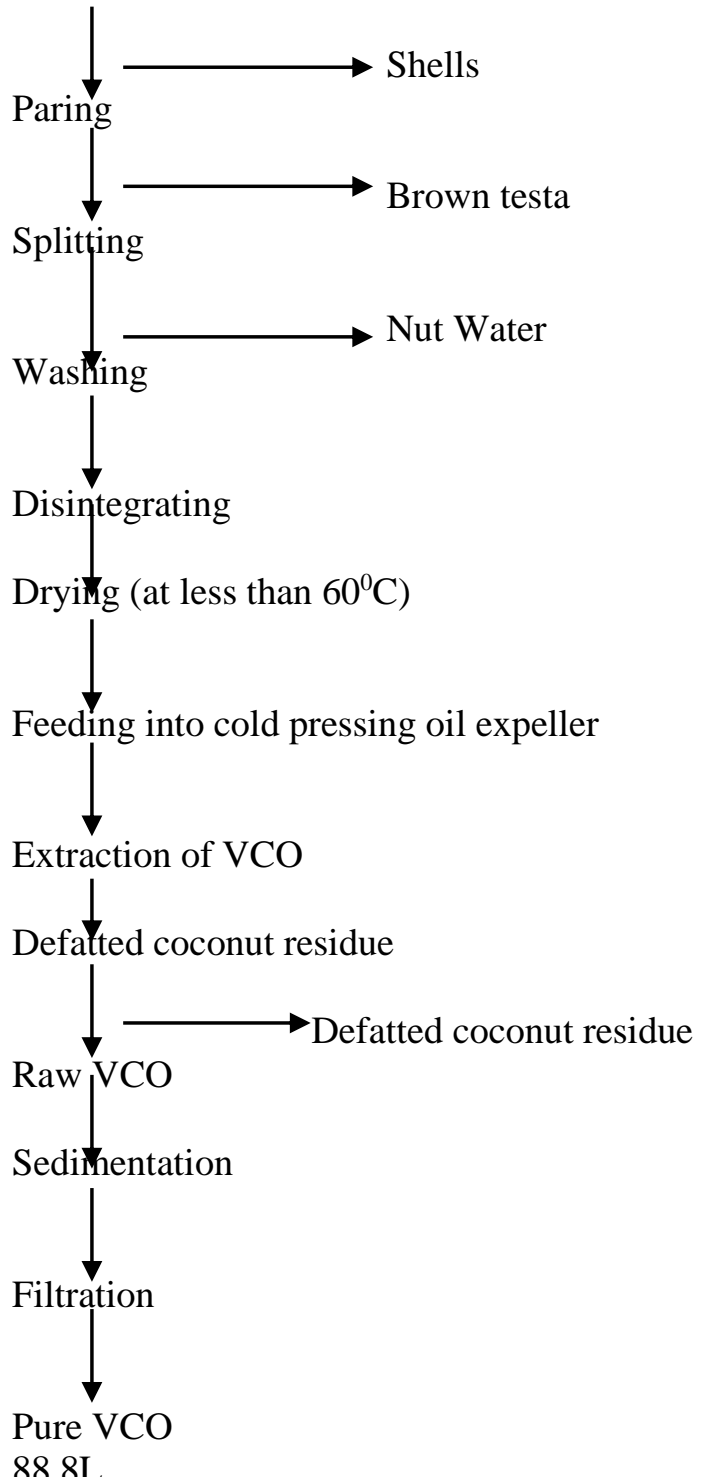

Source: Coconut Processing and Research Division, CRISL. 
Table 1: Processing of 1000 coconuts (per batch) to produce virgin coconut oil: A Cost Analysis

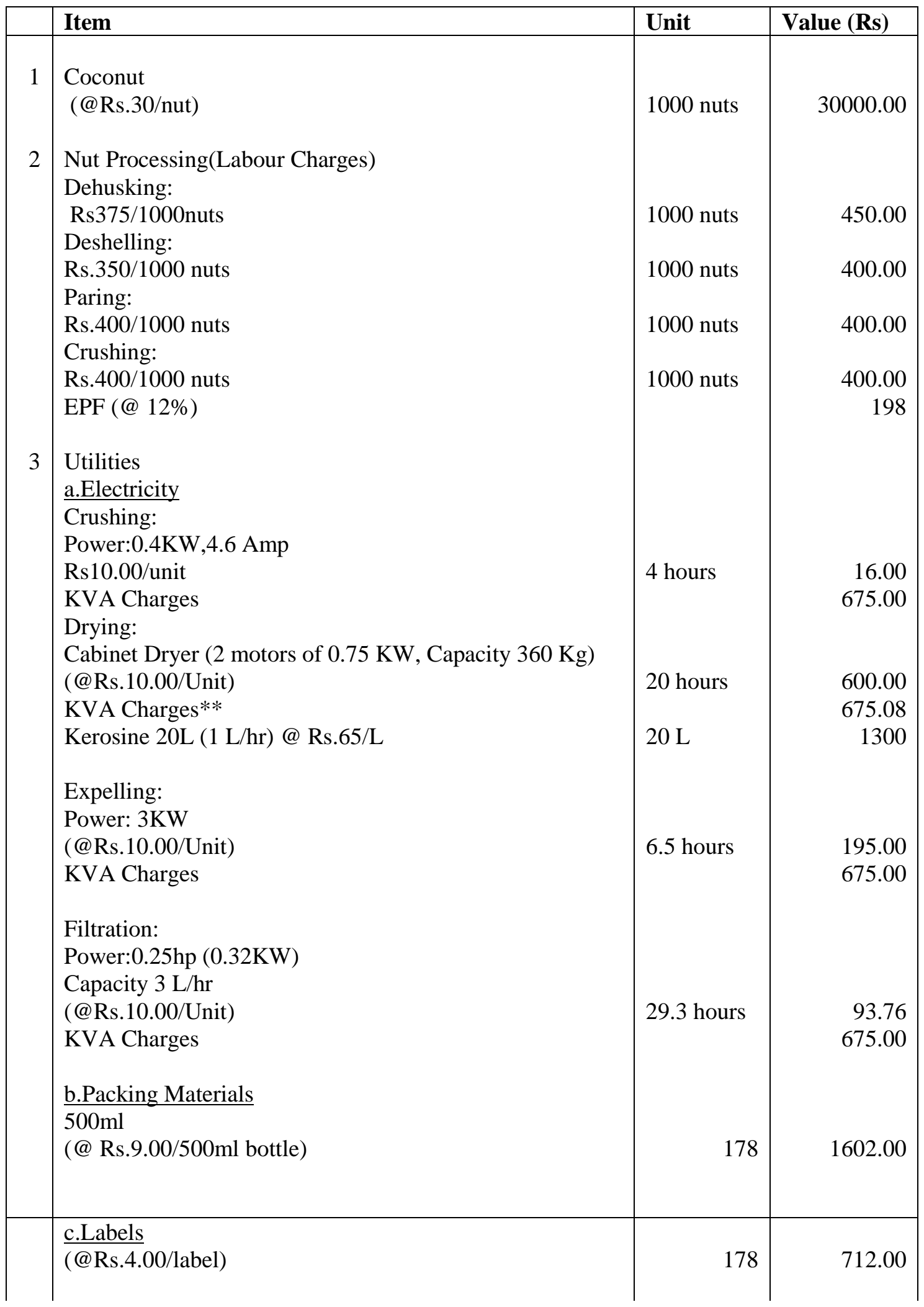




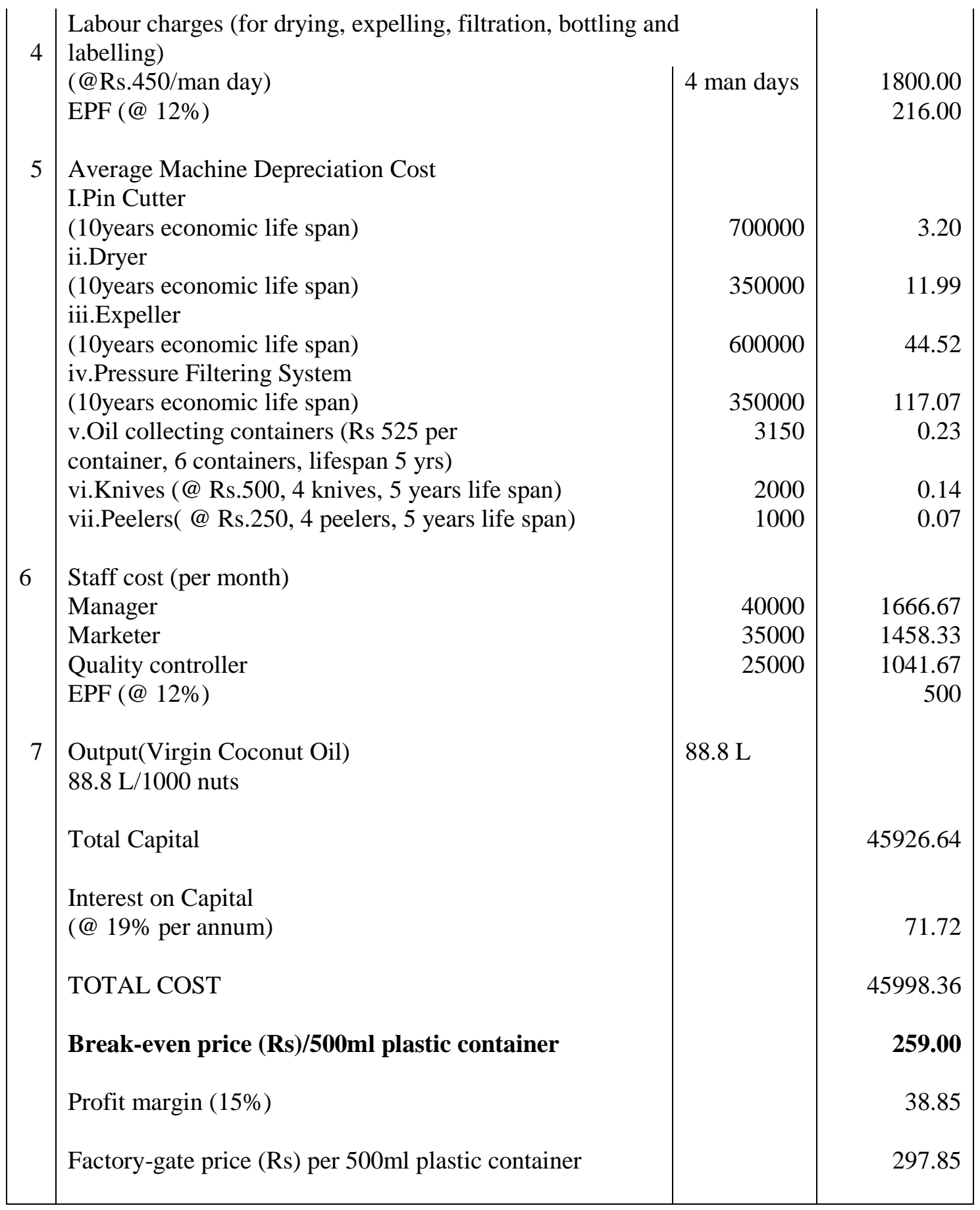

Notes: An average economic life span of 10 years is considered for the machineries.

** - cost incurred in electricity at the time of switching on the machines

The competitiveness of different kernel products in terms of earning profits or the economics of using 1000 nuts for alternative products, VCO yields the highest profit margin. Table 2 illustrates that the net return from newly emerging products has considerably a higher value compared to the traditional products in the export market.

Pay- back period for the investment on machineries 
The pay-back period represents the amount of time that it takes for a capital budgeting project to recover its initial cost (Anon, 2007c).

Pay-back period $=\underline{\text { Cost of project or Investment }}$ Annual Cash Inflows

The initial investment on machineries will be covered within 1.1 months after the commencement of the production. Figure 2 shows the pay-back period under prevailing prices and conditions used in break-even price analysis.

The processing capacity is assumed to be 1000 nuts per 8 hours day and 24 working days per month. The investments on building, transportation, building maintenance are not included here.

\section{Sensitivity Analysis}

This is an analytical technique to test systematically what happens to the earning capacity of a project if event differ from the estimates made about them in planning (Gittinger, 1984). Input and output prices subject to variations. Key inputs used in the production of VCO include coconuts, labour, electricity etc. Of them, price of coconuts is crucial to determine the VCO net return.

The single most important output is VCO, whose price also subject to variations. Therefore, it is important to analyze the changes in net return in response to changes in coconut and $\mathrm{VCO}$ prices.

Table 3 shows the sensitivity of net return for change in world market price of VCO. It shows that VCO production is profitable even if the price of VCO is dropped by $25 \%$. Pay back period increases with this price drop. The project starts to give out negative net return when the price of VCO is dropped by $47 \%$.

Table 4 describes the sensitivity of net return from $\mathrm{VCO}$ for changes in nut price. Even if the nut price increases by $50 \%$, the project is profitable with a pay-back period of 2.2 months to cover the investment on machineries. This shows that the project is more sensitive for $\mathrm{VCO}$ price than nut price.

We considered current nut price (Rs.30) as the base scenario. From November in 2007 to March 2008, there is a sudden jump in nut price contrast to the general nominal price trend (see Figure 3). This price rise is caused by the general reduction of nut yield during this period coupled with the increased nut utilization in the coconut oil industry due to the world market price increase of other imported edible oils. Although these nut prices are extremely high, VCO price increase from US \$ 4 to 8 has offset the nut price rise, making this industry still profitable.

Table 5 describes the sensitivity of net return for simultaneous change in local nut price and world market price of VCO. When the world market price of VCO decreases by $50 \%$, then the net return turns out to be negative even if nut price is increased by $10 \%$. A $50 \%$ reduction in VCO world market price can be compensated even by a $10 \%$ decrease in local nut price. The investor can generate a positive return unless the VCO price decreases by $50 \%$.

The sensitivity analysis that has been conducted so far implies that the net return of VCO production is significantly robust for VCO price reduction and coconut price increases. Despite this promise, there are some

Table 2: Net return from various products produced using 1000 nuts

\begin{tabular}{|l|l|l|l|l|}
\hline Product & Quantity & $\begin{array}{l}\text { Average Total } \\
\text { Cost (Rs) }\end{array}$ & $\begin{array}{l}\text { Gross return } \\
\text { (Rs) }\end{array}$ & $\begin{array}{l}\text { Net Return (Rs/1000 } \\
\text { nuts) }\end{array}$ \\
\hline $\begin{array}{l}\text { Desiccated } \\
\text { Coconut }\end{array}$ & No.1-107kg & 31976 & 30875 & -1101 \\
\hline
\end{tabular}




\begin{tabular}{|c|c|c|c|c|}
\hline Coconut Oil & $\begin{array}{r}\text { No.2-26kg } \\
112 \mathrm{~kg}\end{array}$ & 35707 & 52434 & 16726 \\
\hline Virgin Coconut & $88.8 \mathrm{~L}$ & 24683 & 76012 & $30014^{*}$ \\
\hline Copra & $185 \mathrm{~kg}$ & 30668 & 36000 & 5332 \\
\hline Fresh nut export & 1000 nuts & 30000 & 36000 & 6000 \\
\hline Coconut Paste & $150 \mathrm{~kg}$ & 42000 & 60000 & 18000 \\
\hline
\end{tabular}

Notes: These calculations were based on November 2006 data and slight variation may occur due to price changes and rounding.

Income from byproducts was also considered in calculating gross return.

*Transport and overhead/staff cost are not included. Income from coconut flour (byproduct) is not included.

Source: Pathiraja (2007): Unpublished.

Figure 2: Pay-back period to recover the investment cost on machineries

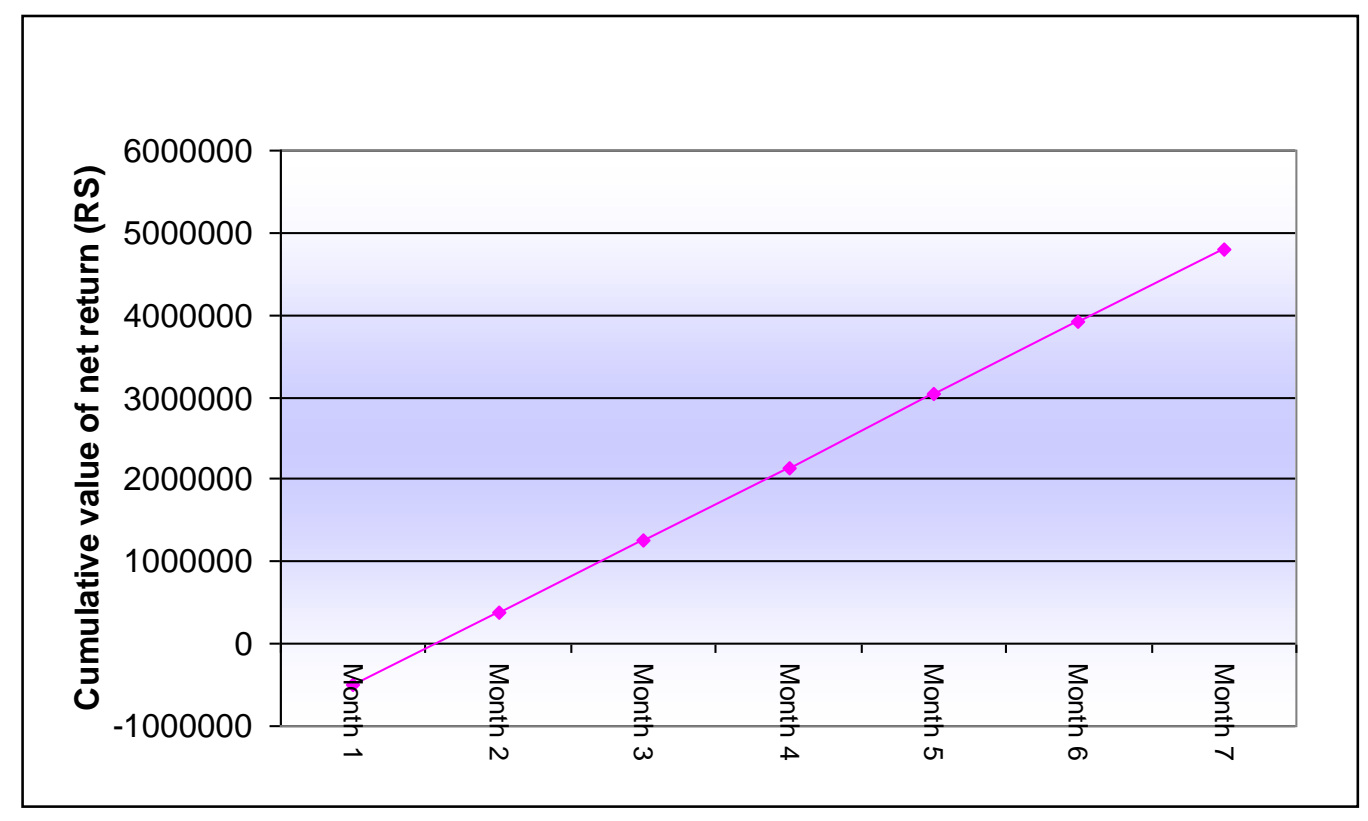

Table 3: Sensitivity of net return derived from VCO with respect to world market price variations of VCO

\begin{tabular}{|c|c|c|c|}
\hline & $\begin{array}{c}\text { Net Return per } \\
1 \text { L of VCO } \\
\text { produced } \\
\text { (Rs/Litre) }\end{array}$ & $\begin{array}{c}\text { Net Return } \\
\text { per 24 hours } \\
\text { day (Rs/Day) }\end{array}$ & $\begin{array}{c}\text { Pay-back } \\
\text { period }\end{array}$ \\
\hline
\end{tabular}




\begin{tabular}{|c|rr|r|l|}
\hline If VCO price & $50 \%$ & 766 & 73119.63 & 0.25 months \\
is increased & $25 \%$ & 552 & 54116.43 & 0.5 months \\
by & $10 \%$ & 423.6 & 42714.51 & 0.75 months \\
& & 338.00 & 35113.23 & 1.2 months \\
Base & & & & \\
Scenario (at & & & & \\
current fob & & & & \\
price of & & & & \\
VCO) & & 252.4 & 27511.95 & 1.5 months \\
& $10 \%$ & 124 & 16110.03 & 3 months \\
If VCO price & $10 \%$ & -90 & -2893.17 & - \\
is reduced by & $25 \%$ & $50 \%$ & & \\
& & & & \\
\hline
\end{tabular}

Figure 3: Change in farm-gate price of nuts over time

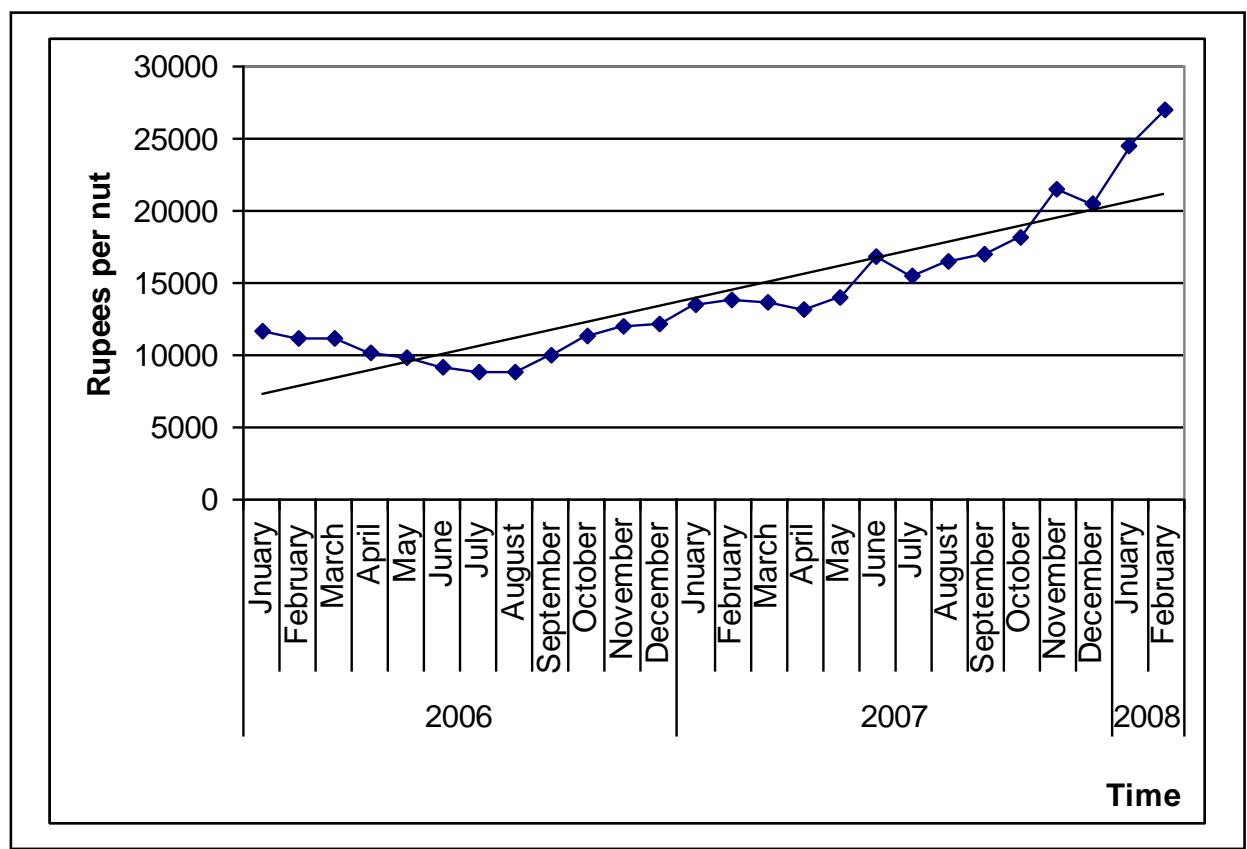

Table 4: Sensitivity of net return for changes in nut price

\begin{tabular}{|c|r|r|r|r|}
\hline \multicolumn{2}{|l|}{} & $\begin{array}{c}\text { Net Return } \\
\text { per 1 L of } \\
\text { VCO } \\
\text { produced } \\
\text { (Rs/Litre) }\end{array}$ & $\begin{array}{c}\text { Net Return } \\
\text { per 24 hours } \\
\text { day (Rs/Day) }\end{array}$ & $\begin{array}{c}\text { Pay-back } \\
\text { period }\end{array}$ \\
\cline { 1 - 1 } If nut price is & $50 \%$ & 168.82 & 20089.80 & 2.3 months \\
\cline { 1 - 2 }
\end{tabular}




\begin{tabular}{|c|c|c|c|c|}
\hline increased by & $25 \%$ & 253.41 & 27601.52 & 1.5 months \\
& $10 \%$ & 304.16 & 32108.54 & 1.25 months \\
$\begin{array}{c}\text { Base Scenario } \\
\text { (at current nut } \\
\text { price) }\end{array}$ & & 338.00 & 35113.23 & 1.2 months \\
If nut price is & $10 \%$ & 371.84 & 38117.91 & 1 months \\
reduced by & $25 \%$ & 422.59 & 42624.94 & 0.8 months \\
& $50 \%$ & 507.18 & 50136.65 & 0.6 months \\
\hline
\end{tabular}

Table 5: Sensitivity of net return for simultaneous change in local nut price and world market price of VCO

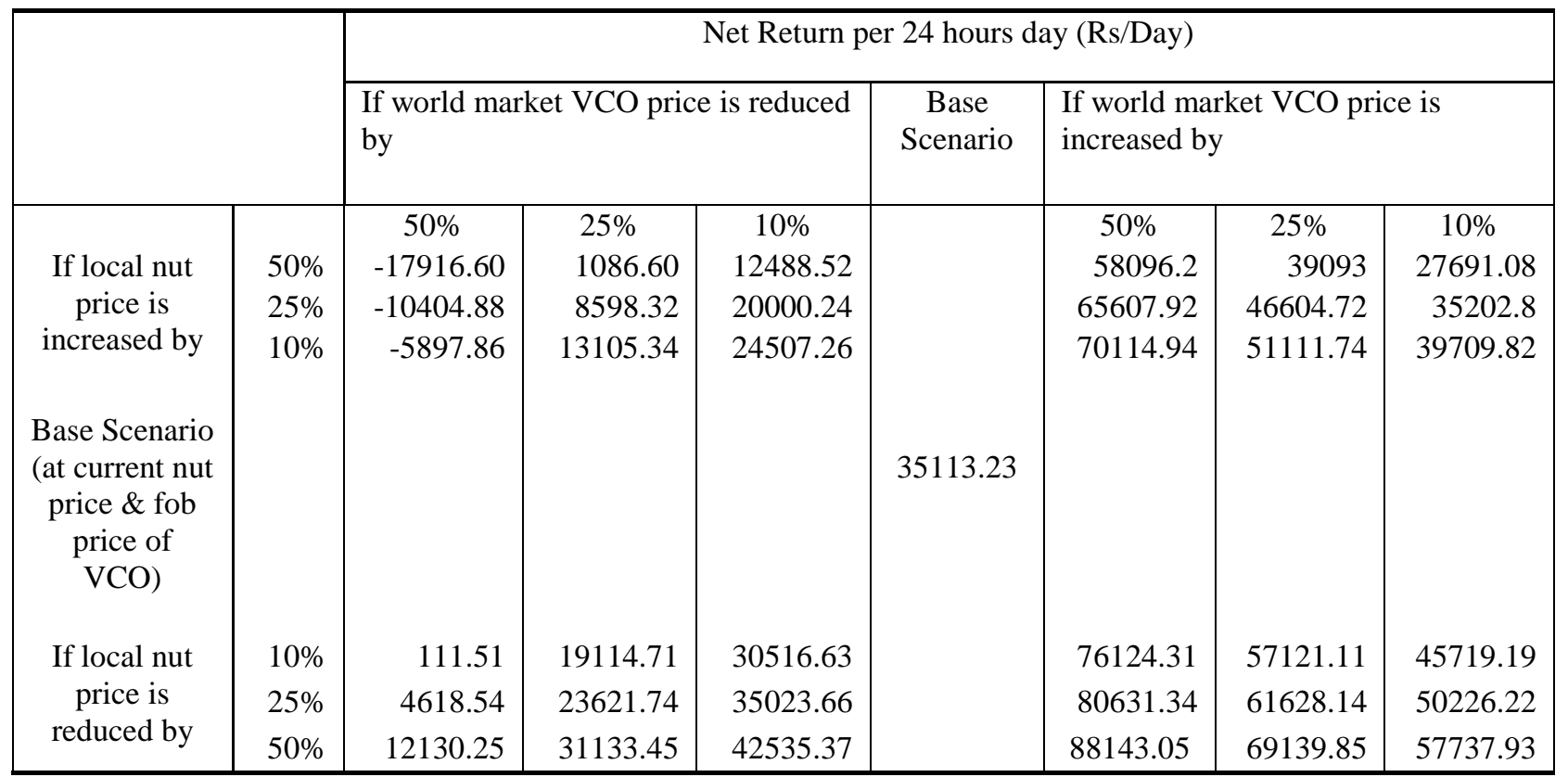

constraints in capturing the foreign market due to lack of information for a new investor. In the Philippines, online trading of VCO is going to be developed through the Philippines Virgin Coconut Oil Association (Muhartoyo, 2005).In Indonesia, Indonesian Centre for Coconut and other Palms Research Institute (ICOPRI) pointed out the possibility of implementing VCO production by farmer groups and provision of micro credit schemes for them (Barlina and Idroes, 2005). Likewise Sri Lanka also should strategize interventions to promote the production and export of this emerging product through her entrepreneurs.

\section{Conclusions and Recommendations}

The economic analysis proved that the net return of VCO production is more sensitive to variations in world market VCO prices than local market nut prices, implying that the world market VCO price is critically influencing the profitability of the VCO industry. The general trend of the world that reflect the shifting 
towards organic products holds promise to strengthen the demand side of the global VCO equation. Equally, the recent global shift to use food crops as a feed stock for bio-fuel industry would likely to restrict the supply side of the global edible oil for edible uses. The combined effect of the above increasing demand for and limited supply of edible oils for edible purposes signals a promising long-term outlook for local VCO industry.

As the profitability of most of the traditional kernel products are found to be more sensitive to the nut price, which is continuously increasing in Sri Lanka, this emerging product appears to be more rewarding to the Sri Lankan coconut industry. This is an enterprise which has a very short pay-back period. Therefore, the government should make arrangements to promote this product and to assist the entrepreneurs in finding export markets and initial investment cost.

\section{Acknowledgements}

Authors wish to express their gratitude to Dr. (Mrs.) C Jayasekera and Mr. J.M.D.T. Everard, respectively Director and Deputy Director (Research), Coconut Research Institute of Sri Lanka (CRISL) for giving permission to publish this research brief. The support given by the staff of the Agricultural Economics Division, CRISL is also highly acknowledged.

\section{References}

Anon, (2007a).Philippines to Benefit from Craze for Virgin Coconut Oil, Manila, February $8^{\text {th }} \quad 2007, \quad$ Asia $\quad$ Pulse. http://sg.biz.yahoo.com/070208/46jqi.html.

Anon, (2007b). Virgin Coconut oil has tremendous export potentials. http://www.Manila Bulletin Online.htm.

Anon, (2007c). Payback period. http://www.12manage.com/methods_payback_pe riod.html.

Barlina, R and Idroes, A. (2005). Farm Level Processing of Virgin Coconut Oil (VCO) and its Economic Implications. Coco Info International, 12 (1):12-16.

Carandang, E.V. (2005). Coconut oil: Uses and issues on its health and neutraceutical benefits.

http://www.coconutoil uses and issues.htm.

Central Bank of Sri Lanka, (2008). Monthly Exchange Rates. http://www.cbsl.lk.

Floresca, F.R. (2004).Virgin Coconut Oil: An Export Winner in the Making. The Philippine STAR, 28 ${ }^{\text {th }}$ November, 2004. http://www.searca.org/ bic.

Gittinger, P. (1984). Economic Analysis of Agricultural Projects. The Johns Hopkins University Press, Baltimore, Maryland 21218, USA. Pp 498.

Muhartoyo, (2005). An Interview with Mr. Paulo P.Mamangun Jr., President, Philippines Virgin Coconut Oil Association, Philippines. Coco Info International, 12 (1):25-27.

Ovasuru, T. (2006). Global Development Affecting the Competitiveness of the Coconut Industry in Papua New Guinea: A country paper for presentation at the 42nd Cocotech meeting held at Manila, Philippines, $21^{\text {st }}-25^{\text {th }}$ Augest, 2006.

Pathiraja, P.M.E.K. (2007). Profitability of different coconut kernel products. Coconut Research Institute, Sri Lanka.

Perera, S.C. (2007). Sri Lanka commences large scale manufacture of virgin coconut oil. http://www.asiatribune.com.

Romulo N Arancon, J.R. (2003). CIDA's Assistance to APCC's Effort in Organic Certification of VCO. http://www.apccsec.org. 
Cord 2008, 24 (1)

Sarian, Z.B. (2007). We must standardize virgin coconut oil. Welcome to Manila Bulletin

htm.http://www.mb.com.ph. Online. 